\title{
GOVERNANCCA DE TI: UM ESTUDO SOBRE O MODELO DA COMPANHIA DE ÁGUAS E ESGOTOS DO RN
}

\author{
José Xavier de Oliveira Lima Segundo, secondx@gmail.com \\ Cláudio Márcio Campos de Mendonça, cmarcio@unifap.br
}

\section{RESUMO}

Um dos componentes da Governança corporativa é a governança de Tecnologia da Informação (TI) que tem como principal objetivo o alinhamento estratégico entre TI e negócio, requisito fundamental para que os investimentos em TI se traduzam na criação de valor para as organizações. Como em muitas empresas, na Companhia de Águas e Esgotos do Rio Grande do Norte - CAERN, o entendimento geral não só da governança corporativa como também da governança de TI ainda é incipiente o que sugere a necessidade de se avaliar como a Governança de TI ocorre na companhia. Assim, o objetivo deste trabalho identificar a estrutura de decisões e arranjos de Governança de TI da Companhia de Águas e Esgotos do RN e apresentar oportunidades de melhorias. Para atingir esses objetivos, foi realizado um estudo de caso, utilizando entrevistas semiestruturadas individuais que abordaram aspectos de difícil identificação através de métodos quantitativos. A pesquisa revelou que, de um modo geral, a Governança de TI da CAERN apresenta um dos três melhores arranjos segundo a pesquisa realizada por Weill e Ross (2006), porém foi identificada a ausência de uma série de boas práticas que, se aplicadas, poderiam promover uma governança mais eficaz, bem como aumentar a percepção da companhia sobre o valor entregue pela TI ao negócio. As oportunidades de melhorias estão baseadas nas boas práticas identificadas nas instituições de melhores resultados segundo ampla pesquisa de Weill e Ross (2006) coma a indicações de implantação de estruturas de tomada de decisão, de processos de alinhamento e de abordagens de comunicação e relacionamento.

Palavras Chaves: Governança de Tl; Governança Corporativa; Alinhamento Estratégico; Tecnologia da Informação. 


\section{INTRODUÇÃO}

Em 2002, veio à tona uma série de escândalos financeiros envolvendo grandes empresas americanas, entre elas, a ENRON que durante anos, diretores da empresa maquiavam os balancetes, enxugavam os prejuízos e inflavam os lucros, uma verdadeira mágica contábil (O ESCÂNDALO... 2002). A gravidade dos fatos minou a confiança dos investidores e, consequentemente, provocou uma forte redução nos preços de ações no mundo todo, em especial nos Estados Unidos. Junto com a preocupação em oferecer mais segurança aos stakesholders (empregados, acionistas, parceiros, clientes, etc.) e reerguer a confiança dos investidores no mercado, o governo dos EUA aperfeiçoou a legislação, exigindo das empresas mais transparência e o aumento do nível de autorregulação. Assim, foi criada em 2002 a lei federal "The U.S. Public Company Accounting Reform and Investor Protection 2002", mais comumente conhecida como Sarbanes-Oxley. Esta lei federal contempla aspectos da governança corporativa e a ética nos negócios de empresas com capital na bolsa de valores de Nova York e Nasdaq, incluindo a segurança de sistemas de informação e o controle de registros.

Nesta época, a governança corporativa já não era novidade e com os então recentes escândalos, ascendeu o interesse sobre o assunto governança corporativa. Com isso, diversos órgãos publicaram diretrizes da boa governança corporativa e muitas empresas adotaram-nas como atrativo para os investidores.

Weill e Ross (2006) destacam em seus estudos uma pesquisa realizada por McKinsey que constatou que alguns investidores preferem pagar ágio, que variam de 13\% (na América do Norte e Oeste Europeu) a 25\% (na Ásia e América do Latina) em empresas que possuem altos padrões de governança, afirmando ainda que grandes instituições atribuem à governança corporativa o mesmo peso que indicadores financeiros quando avaliam decisões de investimento.

A ideia de governança não é novidade. Em seu trabalho, Mendonça (2015) fez um apanhado histórico sobre o tema, desde a sua origem, na década de 1930, com o desenvolvimento dos mercados de capitais. Dois anos depois, Berle e Means (1932), apresentam o problema da agência: como garantir aos investidores que seus recursos sejam aplicados atendendo aos seus interesses? Este problema trata do conflito de interesses entre acionistas e gestores de entidades com propriedade dispersa do capital. Posteriormente, em 1976, Jensen e Meckling reapresentam o problema da agência como a situação em que indivíduos, chamados de agentes, são contratados para representar outros indivíduos, chamados de principais, em que o agente deixa de tomar a melhor decisão para o principal interessado (a organização) e passa a agir visando ao seu próprio interesse.

A necessidade de minimizar problema da agência e dar mais segurança e transparência aos stakesholders fez com que as corporações seguissem uma tendência mundial pela adoção de mecanismos (internos e externos) que orientassem seus processos decisórios. Para Albertin e Albertin (2010), esse movimento, cujo objetivo principal era minimizar conflitos de interesses entre gestores e acionistas, teve início no Reino Unido e nos Estados Unidos, na década de 1990, dando início à governança corporativa. Para Shleifer e Vishny (1997) a governança corporativa e o problema da agência são duas perspectivas fortemente relacionadas. 


\section{ISSN - 2447-178X}

Em 1999 a Organização para a Cooperação e o Desenvolvimento Econômico (OCDE) publicou os "Princípios de Governança Corporativa", definindo a governança corporativa como uma estrutura que determina os objetivos organizacionais e que monitora o desempenho para assegurar a concretização desses objetivos. Citava ainda que, apesar de não existir um modelo único de boa governança corporativa, em muitos países esse papel cabe a um conselho superior, responsável por proteger os direitos dos acionistas, funcionários, credores, ou seja, os stakeholders. 0 conselho, por sua vez, trabalha com uma equipe da alta gerência para implementar princípios de governança que assegurem a eficiência dos processos organizacionais.

Rotta, Hillbrecht e Balbinotto Neto (2005), reconhecem a existência de 3 modelos mundiais de governança: o modelo japonês, baseado em modelo de aglomerado de empresas com interesses similares; o modelo alemão, cujo o foco é a participação dos acionistas, resultando na influência nas decisões dos executivos; e por fim, segundo Silveira (2002), o modelo americano que busca a integração entre os executivos e os acionistas, minimização dos problemas de gerência e como característica marcante a pulverização do controle acionário.

Conforme Mendonça (2015), conclui seu apanhando histórico afirmando que Albertin e Albertin (2010) consideram os escândalos corporativos com organizações como a Enron, Worldcom e Tyco no ano de 2002, fizeram com que o tema ganhasse ainda mais atenção e preocupação por parte das organizações e especialistas do assunto e que diversos autores passaram citar a governança corporativa com um caminho para a minimizar o problema da agência.

De acordo com Denis e McConnell (2003), afirmam que a governança corporativa pode ser definida como um conjunto de mecanismos institucionais baseados pelo mercado, que induz os agentes a tomarem as decisões que maximizem o valor da companhia para os acionistas.

Neste mesmo sentido, Mendonça (2015), define governança corporativa como um conjunto de princípios ou mecanismos que norteiam o processo decisório em uma organização, a fim de que a mesma se torne economicamente sustentável e confiável para seus stakeholders e se minimizem os "problemas de agência

Para Weill e Ross (2006), as empresas concretizam suas estratégias e geram valor de negócio através de seus ativos. As equipes executivas sêniores criam mecanismos para governar a administração e utilização de cada um desses ativos, de forma independente ou em conjunto. Os principais ativos são:

- Ativos humanos: pessoas, habilidades, planos de carreira, treinamento, competências, etc.;

- Ativos financeiros: dinheiro, investimentos, fluxo de caixa, etc.;

- Ativos físicos: prédios, equipamentos, manutenção, segurança, etc.;

- Ativos de Propriedade Intelectual (PI): Know-how de produtos, serviços e processos embutidos nas pessoas e nos sistemas da empresa;

- Ativos de relacionamento: relacionamentos internos e externos, marca; e reputação junto a clientes, fornecedores, órgãos reguladores, etc.;

- Ativos de informação e TI: dados digitalizados, informações e conhecimentos sobre clientes, desempenho de processos, sistemas de informação, etc. 
No Brasil, em 2016, foi aprovada a lei 13.303, também conhecida como a "Lei das Estatais", que confere uma identidade ao regime jurídico das empresas públicas e das sociedades de economia mista, mesclando institutos de direito privado e de direito público. Nela, é estabelecido um conjunto de mecanismos de transparência e governança a serem observados pelas estatais, como regras para divulgação de informações, práticas de gestão de risco, códigos de conduta, formas de fiscalização pelo Estado e pela sociedade, constituição e funcionamento dos conselhos, assim como requisitos mínimos para nomeação de dirigentes (ALVES, 2016).

Para o atendimento às exigências da nova lei, a CAERN mobilizou um grupo de trabalho multidisciplinar e definiu em seu planejamento estratégico alguns projetos com esta finalidade.

Este trabalho está voltado para a governança dos Ativos de TI no âmbito da CAERN e tem como objetivo realizar o mapeamento e análise da sua Governança de TI. 0 estudo busca identificar a estrutura de decisões e arranjos de governança da instituição baseado no modelo de Weill e Ross (2006).

\subsection{Governança de TI}

Atualmente, com a massificação da computação, sistemas de informação e das telecomunicações, as soluções de TI podem suportar toda a cadeia de valor de uma empresa. Para Gonçalves (2012), a informação e a tecnologia representam um dos mais valiosos ativos de uma empresa e cita o IT Governance Institute (ITGI) com a afirmação de que a TI é essencial para gerenciar transações, informações e conhecimentos necessários para iniciar e sustentar as atividades econômicas e sociais de uma organização. Ainda sobre a importância da TI, Mahoney (2007) afirma que a atuação da TI vai além de habilitar os processos de negócio, permite também a criação de novos processos de negócio e de tecnologia. Weill e Ross (2006) consideram que a informação e a TI estão entre os principais ativos de uma organização e, normalmente, os menos entendidos, além de ser uma área em evidência que recebe crescentes investimentos e proporciona aumento nos lucros da organização.

Assim, para que o potencial da TI gere os resultados esperados, concretize estratégias corporativas e gere valor de negócio, é necessário que suas ações sejam direcionadas aos objetivos estratégicos da organização. Para Mendonça (2015), a integração entre a estratégia de negócio e a estratégia de TI deve ser consolidada para que se consiga alcançar os níveis de qualidade desejados pelos acionistas e clientes, e conclui que a Governança de Tecnologia da Informação pode favorecer esse alinhamento.

Para Lunardi, Becker e Maçada (2012), governança de TI é um tema de interesse crescente por parte dos acadêmicos e executivos, indicando uma mudança do papel da TI e o crescimento da sua importância para as organizações e, consequentemente, da necessidade de garantir que ela seja efetivamente gerenciada. O ITGI enfatiza em seu Board Briefing On IT Governance (2003) que a governança de TI deve fazer parte da governança corporativa, permitindo que a tecnologia da informação seja vista como parte integral da organização.

Devido à importância da TI para as organizações é necessário torná-la mais profissional, nesse sentido, a governança de TI necessita ser levada em consideração (WEILL; ROSS, 2006).

Existem várias definições para governança de TI, Weill e Ross (2006) entendem a governança de $\mathrm{TI}$ como um conjunto de práticas de gestão de TI, que objetivam, principalmente, equilibrar os 


\section{ISSN - 2447-178X}

riscos e oportunidades em ambientes competitivos, facilitar a tomada de decisão, controlar custos, pessoas, contratos, garantir o fornecimento de serviços de terceiros, além de esclarecer quem são os tomadores de decisão. Eles aprofundam o conceito como sendo "a especificação dos direitos decisórios e do framework de responsabilidades para estimular comportamentos desejáveis na utilização da TI" (WEILL; ROSS, 2006, p. 8). O ITGI define que "governança de TI é de responsabilidade dos executivos e da alta direção, consistindo em aspectos de liderança, estrutura organizacional e processos que garantam que a área de TI da organização suporte e aprimore os objetivos e as estratégias da organização". Já Lunardi $(2008$, p. 38) define que:

Governança de TI consiste no sistema responsável pela distribuição de responsabilidades e direitos sobre as decisões de Tl, bem como pelo gerenciamento e controle dos recursos tecnológicos da organização, buscando, dessa forma, garantir o alinhamento da TI com as estratégias e objetivos organizacionais.

Em sua pesquisa, Mendonça (2015, p. 44) afirma que diversas definições de governança de TI possuem um aspecto comum, que é o processo decisório da TI e sua relação com o negócio e conclui que:

A governança de $\mathrm{TI}$ se apresenta como uma importante ferramenta capaz de permitir o alinhamento entre as estratégias de negócio e da $\mathrm{TI}$, visto que favorece um maior profissionalismo aos processos decisórios da TI.

Para Martin, Santos e Dias Filho (2004), um sistema de governança estabelece mecanismos, estruturas e incentivos que compõem o sistema de controle de gestão da empresa e direciona o comportamento dos gestores.

\subsubsection{Matriz de Arranjos de Governança}

A pesquisa realizada por Weill e Ross (2006) em 256 empresas (incluindo as esferas públicas, privadas e organizações não governamentais), de diferentes portes e em todos os continentes, demonstram que as empresas que possuem melhores resultados são aquelas que conseguiram obter alinhamento da TI aos objetivos do negócio, através de mecanismos de Governança que definem bem o papel da TI dentro da organização e as responsabilidades sobre as decisões chave de TI, utilizando a TI de forma estratégica para o alcance dos objetivos do negócio e, consequentemente, melhores desempenhos. Essa pesquisa identificou que as três questões principais que devem ser respondidas sobre a Governança de TI são:

I. Decisões Chave: Quais decisões devem ser tomadas para garantir a gestão e o uso eficazes de TI? 


\section{ISSN - 2447-178X}

II. Tomadores de Decisão: Quem deve tomar essas decisões?

III. Mecanismos de Governança de TI: Como essas decisões serão tomadas e monitoradas?

Sobre a primeira pergunta, a pesquisa apontou que as decisões que devem ser tomadas para garantir a gestão e o uso eficazes de TI são:

- Princípios de TI - esclarece o papel do negócio e da TI.

- Arquitetura de $\mathrm{TI}$ - define os requisitos de integração e padronização.

- Infraestrutura de $\mathrm{TI}$ - determina serviços compartilhados e de suporte.

- Necessidades de Aplicações de Negócio - especifica a necessidade comercial de aplicações de TI compradas ou desenvolvidas.

- Investimento e priorização de TI - escolhe quais iniciativas financiar e quanto gastar.

As cinco decisões chave estão inter-relacionadas e requerem vinculação para que haja uma governança eficaz. A Figura 1 enfatiza suas interconexões críticas.

\section{DECISÕES SOBRE OS PRINCÍPIOS DE TI}

DECLARAÇÕES DE ALTO NÍVEL SOBRE COMO A TI É UTILIZADA NO NEGÓCIO

\section{Decisões sobre a arquitetura de TI}

Organização lógica de dados, aplicações

e infraestruturas, definida a partir de um

conjunto de políticas, relacionamentos e

opções técnicas adotadas para obter a

padronização e a integração técnica e de

negócio desejadas.
Decisões sobre a infraestrutura de $\mathrm{TI}$

Serviços de TI coordenados de maneira centralizada e compartilhados, que provêm a base para a capacidade de TI da empresa.

Necessidades de aplicações de negócio Especificação da necessidade de negócio de aplicações de TI adquiridas no mercado ou desenvolvidas internamente.
Decisões sobre os investimentos e a priorização da $\mathrm{TI}$ Decisões sobre o quanto e onde investir em $\mathrm{TI}$, incluindo a aprovação de projetos e as técnicas de justificação.

Figura 1- Inter-relação entre as decisões chave da Governança de TI.

Nota. Fonte: Weill e Ross (2006)

As decisões sobre os Princípios de TI explicitam os objetivos empresariais da TI. Assim, estão na parte superior do diagrama, estabelecendo diretrizes para as outras decisões. Os princípios de $\mathrm{TI}$, se bem articulados na empresa, tornam-se parte do vocabulário administrativo e podem ser discutidos, debatidos, recusados ou aprimorados. Já as decisões sobre Arquitetura de TI convertem os Princípios de $\mathrm{Tl}$ em requisitos de integração e padronização, delineando um guia técnico para promover as capacidades necessárias. As decisões relativas aos Investimentos e à Priorização da TI mobilizam recursos para converter princípios em sistemas. As decisões referentes à Infraestrutura e Aplicações fluem de cima para baixo, ou seja, dos Princípios, da Arquitetura e dos critérios de investimento em TI. A Infraestrutura gera as capacidades necessárias de TI e as Aplicações fazem uso dessas capacidades (WEILL; ROSS, 2006).

Quanto à segunda pergunta, Weill e Ross (2006) identificaram nas organizações pesquisadas os principais tomadores de decisão e os classificaram através de arquétipos, conforme a seguir. 
- Monarquia de negócio - as decisões são tomadas por um grupo de executivos de negócio ou executivos individuais (CxOs). Inclui comitês de executivos seniores de negócio (podendo incluir o ClO). Exclui executivos de TI que atuem independentemente. Na CAERN este grupo equivaleria à diretoria colegiada ou aos diretores individualmente.

- Monarquia de $\mathrm{TI}$ - as decisões são tomadas por indivíduos ou grupos executivos de TI. Na CAERN este grupo equivaleria à GTI, ou um comitê formado por líderes da GTI.

- Feudalismo - as decisões são tomadas por líderes das unidades de negócio, detentores de processos-chave ou seus delegados. Na CAERN não há em sua estrutura unidades de negócio, neste caso, seriam decisões tomadas por detentores dos principais processos da companhia.

- Federalismo - as decisões são tomadas por executivos do nível de diretoria (c-level) e grupos de negócio (e.g., processos ou unidades de negócio); incluindo executivos de TI como participantes adicionais. Para a CAERN, seriam decisões tomadas por pela diretoria colegiada com a GTI e os detentores dos principais processos da companhia.

- Duopólio de $\mathrm{TI}$ - as decisões são tomadas em conjunto entre executivos de TI e algum outro grupo (e.g., os $\mathrm{CxOs}$ ou os líderes de unidades de negócio ou os líderes de processos). $\mathrm{Na}$ CAERN seria a GTI (ou comitê de líderes da GTI) com a Diretoria Colegiada ou grupo de líderes dos principais processos da companhia. No estudo de Weill e Ross 92006) afirmam que os duopólios de TI assumem, frequentemente, uma de duas formas:

- Roda de Bicicleta: configura-se por um grupo central de TI que se relaciona bilateralmente com várias unidades de negócio em volta, dando atenção individual a elas e suportando toda a empresa;

- Estrutura em forma de $T$ : é caracterizada pela sobreposição de dois comitês: um comitê executivo (parte horizontal do T) composto de administradores da área comercial e um comitê de TI (parte vertical do T) formado por técnicos. Nessa sobreposição, um pequeno grupo de pessoas participa de ambos os comitês para coordenar e garantir a sobreposição, formando assim, o duopólio entre o grupo central de TI e a equipe de alta gerência.

- Anarquia - Decisão é tomada por cada usuário individual por pequenos grupos.

Cada arquétipo identifica quem toma a decisão de TI. Utilizando uma matriz de arranjos de governança (Figura 2) é possível especificar os direitos decisórios, ou seja, quem é responsável por tomar cada umas das decisões chave. 
Quais arranjos de governança funcionam melhor

\section{OS TRÊS MELHORES ARRANJOS DE GOVERNANÇA}

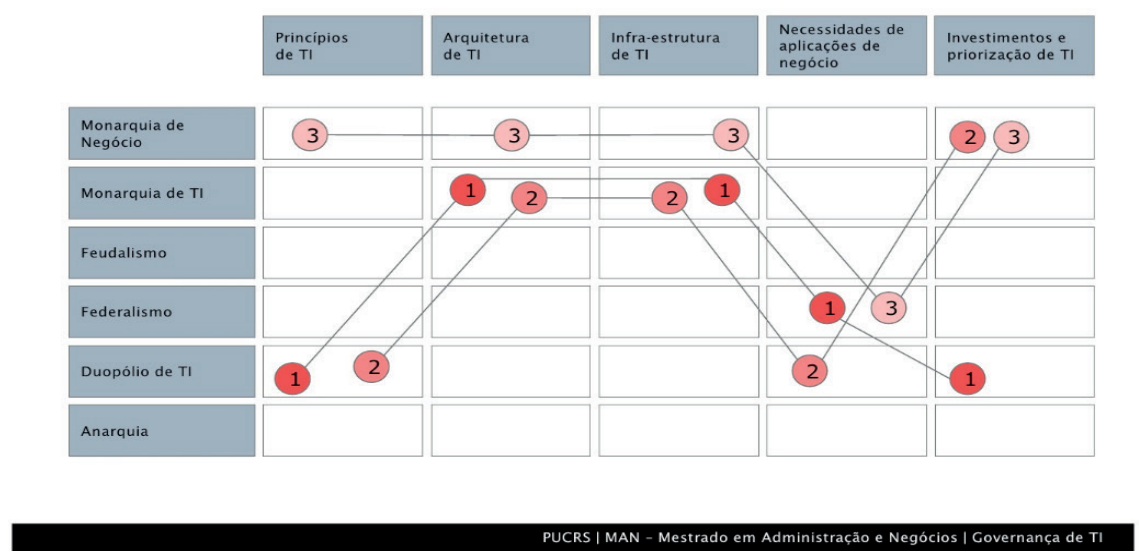

Figura 2 - Três Melhores Arranjos de Governança de TI.

Nota. Fonte: Weill e Ross (2006)

Na Figura 2, Weill e Ross (2006) apresentam os três padrões mais bem-sucedidos, em termos de desempenho de governança. Todos os três equilibram múltiplos objetivos de desempenho, como custo, crescimento e flexibilidade. Como é possível perceber, cada uma das decisões chave de TI é tomada não apenas pela área de $\mathrm{Tl}$, mas por outras áreas importantes da organização, pois não são apenas questões de tecnologia, mas sim, como a TI poderá contribuir para que a empresa atinja seus objetivos.

No arranjo 1 as decisões sobre Princípios de TI e Investimento e Priorização de TI são tomadas em duopólio (CxOs e a TI, possivelmente com comitês em forma de T). Decisões de Arquitetura de TI e Estratégia de Infraestrutura de TI são tomadas através de monarquias de TI, já as Necessidades de Aplicações de Negócio são tomadas através de federalismo. Weill e Ross (2006) consideram que esse arranjo requer que os grupos de TI compreendam as necessidades de negócio e que negócio e TI tenham confiança mútua. Para eles o modelo federalista para as Aplicações de Negócio pode aproveitar possíveis sinergias entre as áreas de negócio, assim como o faria o duopólio em forma de T para Investimentos.

O arranjo 2 é similar ao 1, porém com um duopólio para Necessidades de Aplicação e uma monarquia para Investimentos. Segundo Weill e Ross (2006) esse arranjo funciona bem para empresas com poucas sinergias que utilizem um duopólio "roda de bicicleta" para as necessidades de aplicações.

0 arranjo 3 é o mais centralizado, com monarquias de negócio para todas as decisões, exceto o federalismo para as Necessidades de Aplicações de Negócio. Essa abordagem foi identificada na pesquisa de Weill e Ross (2006, p. 136) como típicas em firmas com uma única unidade de negócio ou nos casos onde a lucratividade ou o controle de custos é mais importante. 
Esse arranjo requer líderes de negócio que conheçam e se importem com questões de $\mathrm{TI}$ - o que se consegue muitas vezes com o $\mathrm{ClO}$ educando a equipe administrativa sênior. Esse arranjo também é conveniente quando grandes mudanças estão em curso e os direitos decisórios devem ser mantidos com punho firme (durante fusões, grandes cortes de despesa, crises e assim por diante).

\subsubsection{Mecanismos de Governança}

A terceira questão, que se refere à forma com que são tomadas e monitoradas as decisões de TI, trata de estabelecer os mecanismos para implementar a governança eficaz da TI e encorajar comportamentos desejáveis nas pessoas. Para Weill e Ross (2006) a implementação da governança de TI se dá por três tipos de mecanismos, são eles:

- Estruturas de tomada de decisão

- Processos de alinhamento

- Abordagens de comunicação

As estruturas de tomada de decisão envolvem a existência de papéis e responsabilidades claramente definidos e a existência de comitês para garantir o alinhamento entre $\mathrm{Tl}$ e o negócio (OLIVEIRA, 2009). Para Luftman (2000), o alinhamento deve explicitar não apenas como a TI se harmoniza com o negócio, mas também como o negócio poderia ou deveria estar em harmonia com a TI. Oliveira (2009) conclui, desta forma, que o alinhamento evolui para uma relação em que a função de Tl e outras funções do negócio adaptam suas estratégias reciprocamente.

De acordo com Miorando e Ribeiro (2014), através das estruturas deve ser possível entender a maneira como a função de TI está organizada e a localização da TI no organograma da empresa e cita como exemplos de assuntos que devem ser tratados na definição das estruturas de governança de TI:

- Estrutura Organizacional da Tl;

- Papéis e responsabilidades;

- Comitê estratégico de Tl;

- Comitê diretor de Tl;

- Administradores de TI.

São as estruturas organizacionais que permitem alocar responsabilidades decisórias com base nos arquétipos pré-definidos.

O segundo tipo de mecanismos para a implementação da governança são os processos de alinhamento que são técnicas da administração de TI para assegurar o envolvimento geral na administração e utilização efetiva da TI, assegurando que os comportamentos cotidianos sejam consistentes com as políticas de TI e contribuam com as decisões. De acordo com Weill e Ross (2006), os principais processos de alinhamento incluem: 


\section{ISSN - 2447-178X}

- Processo de aprovação de investimentos em TI: assegura que os investimentos em TI gerem retornos significativos para a empresa em comparação a outras oportunidades alternativas de investimento.

- Processo de exceções à arquitetura: ajuda a entender as necessidades de negócio específicas e determinar quando os padrões existentes estão se tornando obsoletos. Sem nenhum processo viável de exceções, as unidades de negócio ignoram os padrões da empresa e implementam exceções sem nenhuma aprovação.

- Acordos de nível de serviço: enumeram os serviços disponíveis, os níveis alternativos de qualidade e os respectivos custos. Os Acordos de nível de serviço estimulam comparações com provedores externos, auxiliando na prestação de serviços internos com boa relação custo/benefício ou na decisão de terceirizar alguns serviços de infraestrutura.

- Acompanhamento de projetos: desenvolve a disciplina para acompanhar o progresso de projetos individuais de TI. As empresas podem utilizar um modelo conhecido, como o Modelo de Maturidade da Capacidade, ou uma metodologia de gestão de projetos desenvolvida internamente.

- Rastreamento formal do valor de negócio: rastreia formalmente o valor de negócio da TI, aumenta o aprendizado organizacional sobre o valor de iniciativas habilitadas pela TI e ajuda executivos tanto de negócios quanto de TI a compreender as fontes e obstáculos para gerar valor a partir dos investimentos realizados.

Por fim, para implementação da governança, estão os mecanismos relacionados às abordagens de comunicação que representam os canais e esforços de educação que disseminam, por toda a empresa, os princípios, políticas, decisões e processos de Governança de Tl e os respectivos comportamentos desejáveis. Para Weill e Ross (2006), entre as principais abordagens de comunicação estão:

- Comunicação da alta gerência: comunicados que esclarecem prioridades e demonstram comprometimento. A clareza quanto ao comprometimento ajuda todos a concentrar sua atenção nos objetivos estratégicos.

- Comitês formais: além da participação nas decisões no nível executivo, os comitês também tomam decisões de governança de níveis inferiores e incumbem-se de decisões de alto nível.

- Escritório da Governança de TI: Comunica os processos e os propósitos da Governança e fornece um dono à Governança de Tl, objetivando a colaboração entre os mecanismos.

- Portais baseados na Web: provêm um canal central de comunicação para as empresas. Os portais aumentam a transparência da Governança ao disponibilizar as políticas, os padrões, o desempenho e algumas vezes os debates da empresa.

Na figura 3, estão apresentados os principais mecanismos de governança de TI pesquisada por Weill e Ross (2006). Nela estão relacionadas, o percentual de utilização do mecanismo nas empresas e suas respectivas classificações de eficiência. 


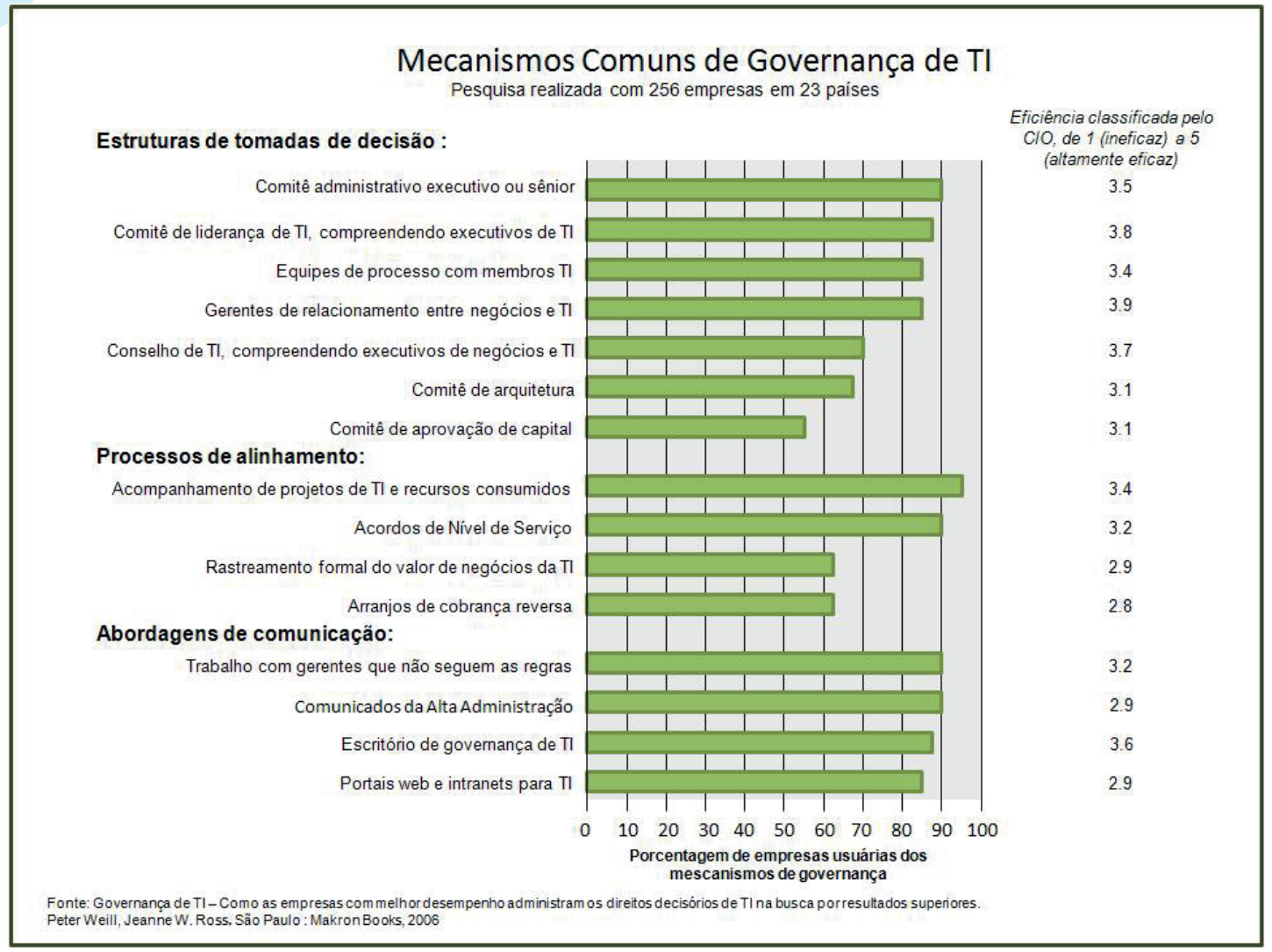

Figura 3 - Mecanismos Comuns de Governança de TI

Fonte: Weill e Ross (2006)

Para organizações do setor público e organizações não-governamentais com melhor desempenho, Weill e Ross (2006) identificam os seguintes mecanismos:

- Comitês executivos concentrados em todos os ativos-chaves, inclusive a Tl;

- Conselho de TI, incluindo executivos de negócios e Tl;

- Comitê de liderança de TI, incluindo executivos de Tl;

- Comitê de arquitetura;

- Acompanhamento de projetos de TI e recursos consumidos;

- Gerentes de relacionamento entre negócios e TI.

\section{METODOLOGIA}

A abordagem qualitativa tem sido frequentemente utilizada em estudos voltados para a compreensão da vida humana em grupos, em campos como sociologia, antropologia, psicologia, dentre outros das ciências sociais (CESAR, 2005). Para Denzin e Loncoln (2000), a abordagem qualitativa abrange estudos nos quais se localiza o observador no mundo, constituindo-se, portanto, em um enfoque naturalístico e interpretativo da realidade.

Para Cesar (2005), as pesquisas de natureza qualitativa envolvem uma grande variedade de materiais empíricos, que podem ser Estudos de Caso, experiências pessoais, histórias de vida, relatos 
de introspecções, produções e artefatos culturais, interações, enfim, materiais que descrevam a rotina e os significados da vida humana em grupos. Quanto ao Estudo de Caso, Cesar (2005) afirma, que o método permite que seja analisada uma situação na qual não se possam fazer interferências no sentido de manipular comportamentos relevantes; neste método os dados são coletados a partir de múltiplas fontes, todas baseadas em relatos, documentos ou observações.

Dessa forma, esta pesquisa se caracteriza como um estudo de caso e utiliza uma abordagem qualitativa, tendo como subsídio muitas informações das experiências pessoais do autor, ao longo de nove anos de trabalho na instituição pesquisada, estando há três anos com Gerente de Tecnologia da Informação. Além disso, foram realizas entrevistas semiestruturadas com oito gestores das áreas de negócio e cinco líderes de TI, totalizando treze pessoas pesquisadas. Ambos os grupos de participantes (TI e negócio) contaram com representantes de diferentes níveis hierárquicos (diretoria, assessoria, gerência e chefia), que ampliaram o campo de percepção do pesquisador e na obtenção de documentos relativos à instituição.

O estudo tratou do caso da Governança de TI da Companhia de Águas e Esgotos do RN e utilizou com principal instrumento um formulário com perguntas representativas para cada decisão chave de $\mathrm{TI}$, bem como todo o modelo de matriz de arranjos de governança definido por Weill e Ross (2006) cuja elaboração se deu através de suas pesquisas em mais de 256 empresas em todo o mundo.

Lakatos e Marconi (2011) afirmam que a pesquisa explicativa registra fatos, analisa-os, interpretaos e identifica suas causas. Essa prática visa ampliar generalizações, definir leis mais amplas, estruturar e definir modelos teóricos, relacionar hipóteses em uma visão mais unitária do universo ou âmbito produtivo em geral e gerar hipóteses ou ideias por força de dedução lógica. Sob este aspecto, para a análise dos resultados, o método utilizado foi o explicativo através do registro, análise e intepretação dos fatos a fim de identificar o arranjo de governança praticado pela instituição e, com base na bibliografia, forma propostos mecanismos de governanças como oportunidades de melhoria.

\section{OBJETO DE ESTUDO: A CAERN}

A Companhia de Águas e Esgotos do Rio Grande do Norte - CAERN, é uma sociedade anônima de economia mista e foi constituída mediante autorização da Lei Nº 3.742, de 26 de junho de 1969, alterada pela Lei № 4747, de 06 de julho de 1978, vinculada à Secretaria De Estado Do Meio Ambiente e dos Recursos Hídricos - SEMARH, e regida pelas referidas Leis, pela Lei Federal de № 6.404 de 15 de dezembro de 1975, pelo Estatuto e demais disposições que Ihe forem aplicáveis, com sede na Avenida Senador Salgado Filho, 1555 - Tirol - Natal/RN.

Tem como missão "contribuir para melhoria da qualidade de vida da população do RN, satisfazendo suas necessidades de abastecimento de água e esgotamento sanitário, respeitando os fatores sociais, econômicos e ambientais". Como visão a CAERN busca "obter reconhecimento da população e do poder público do Rio Grande do Norte na universalização dos serviços de água e esgotos com qualidade e sustentabilidade". A CAERN conta com 165 (cento e sessenta e cinco) sistemas de abastecimento de água distribuídos em 153 (cento e cinquenta e três) sedes de municípios e 13 
(treze) localidades. Opera 40 (quarenta) sistemas de esgoto em 39 (trinta e nove) municípios e 1 (uma) localidade (Praia de Pipa). Apenas 15 (quinze) cidades do Estado possuem sistemas de abastecimento de água autônomo, ou seja, não são mantidos pela CAERN (CAERN, 2013).

A CAERN tem suas relações de trabalho regidas pela Consolidação das Leis Trabalhistas (CLT), e a forma de admissão do colaborador se dá por concurso público, já que a empresa tem como seu maior acionista o Governo do Estado do RN.

De 2008 a 2013 foram realizados quatro concursos públicos que permitiram não só preencher grande demanda por funcionários, como também renovar sua forma de trabalhar. A entrada de novos profissionais permitiu a adoção de novas tecnologias, ferramentas, processos e controle o que vem ocasionando melhorias gradativas em sua gestão.

Em 2014, a CAERN foi classificada entre as 250 melhores empresas do país pela revista Época Negócios, através da avaliação de seis categorias: Desempenho Financeiro, Governança Corporativa, Capacidade de Inovar, Responsabilidade Socioambiental, Práticas de RH e Visão de Futuro. Além do ranking geral, a publicação apresenta as melhores por área e dimensões. Na categoria Água e Saneamento, a CAERN aparece em $5^{\circ}$ lugar na dimensão Desempenho Financeiro e em $4^{\circ}$ lugar na dimensão Capacidade de Inovar (PAULO FREIRE, 2014).

Atualmente possui, aproximadamente, 2.300 (dois mil e trezentos) colaboradores distribuídos em quase 200 (duzentas) unidades administrativas. Sua estrutura organizacional é extensa e organizada funcionalmente, ou seja, utiliza a função como maneira de dividir áreas de responsabilidade e autoridade. De uma forma simplificada, as unidades administrativas estão agrupadas em 7 (sete) regiões: Natal, Regional Agreste Trairi (sede em Parnamirim), Regional Mato Grande (sede em Macaíba), Regional Seridó (sede em Caicó), Regional Sertão Central (sede em Assú), Regional Oeste (sede em Mossoró) e Regional Alto Oeste (sede em Pau dos Ferros).

\subsection{Objetivos Estratégicos da CAERN}

A CAERN possui um planejamento estratégico, baseado na metodologia do Balanced Scorecard (BSC), elaborado para o período de 2017 a 2021, considerando as cinco perspectivas: Aprendizado e Conhecimento, Processos Internos Críticos, Econômico-financeira, Clientes e Sociedade. Cada perspectiva contempla um conjunto de Objetivos Estratégicos (OE), totalizando dezesseis objetivos.

Cada um dos objetivos estratégicos tem pelo menos um projeto estratégico e este deve estabelecer seus indicadores que permitam seu acompanhamento, estar alinhado ao planejamento orçamentário e estar relacionado com uma meta para o exercício anual seguinte. Os projetos são formulados e revisados anualmente para o alcance dos objetivos estratégicos, sempre observando os riscos envolvidos e as perspectivas a que estão relacionadas, ou seja, as diretrizes da Companhia. 0 Mapa Estratégico da CAERN encontra-se ilustrado na Figura 4. 


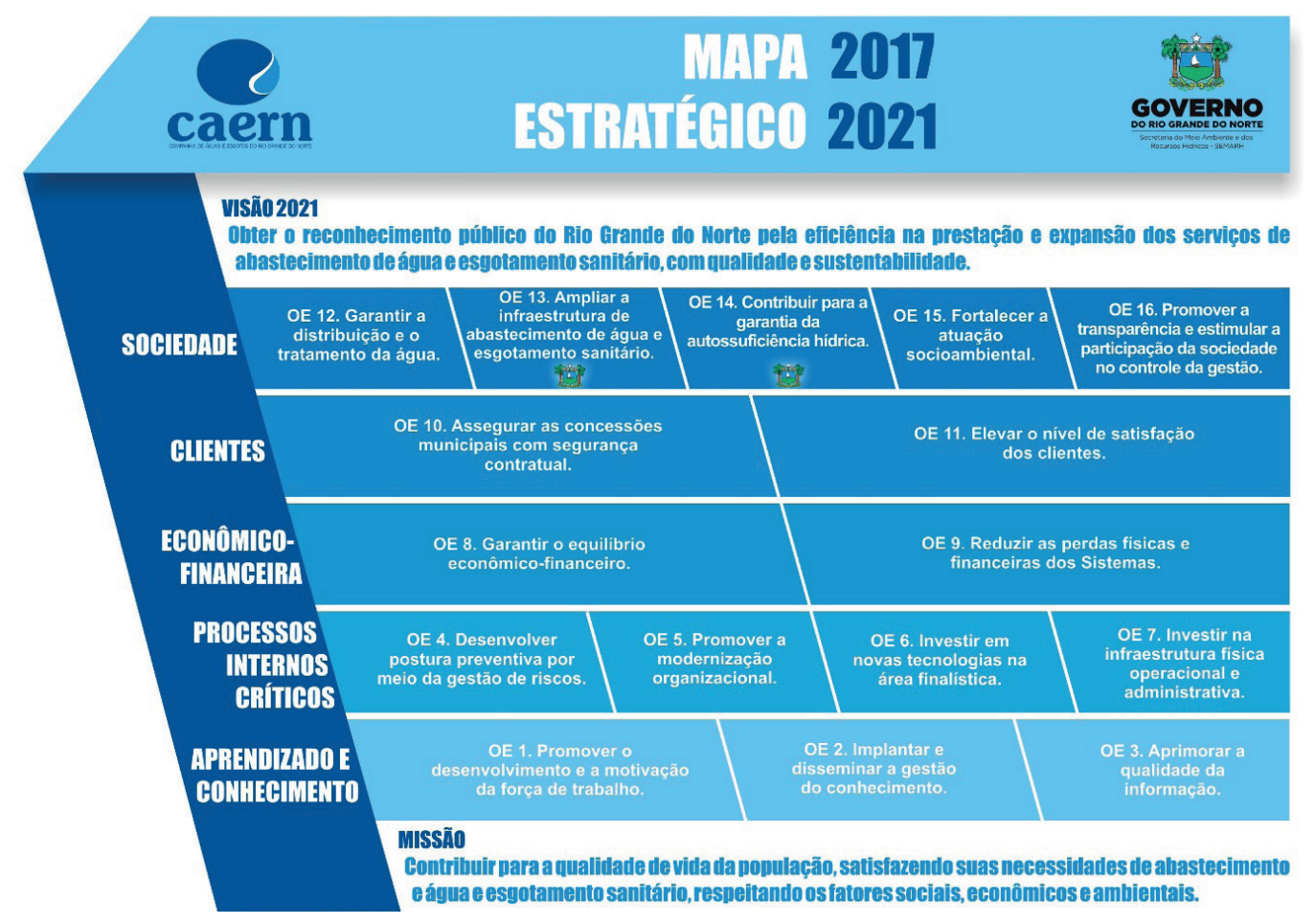

Figura 4-Mapa Estratégico 2017 a 2021 da CAERN.

Nota. Fonte: CAERN.

Pode-se identificar entre os objetivos estratégicos que em nenhum deles a TI está explicitamente incluída e, portanto, não existe nenhum objetivo que evidencie a busca do alinhamento estratégico do negócio com a TI.

\subsection{Macroprocessos da CAERN}

Atualmente, existem na CAERN quase 50 sistemas diferentes, se considerados os módulos do ERP. Estes sistemas atendem a diferentes processos de diferentes áreas da companhia. De acordo com recente (2017) levantamento realizado pela Assessoria de Gestão Empresarial - AGT, setor responsável pelo mapeamento de processos da CAERN, os principais processos da Companhia totalizam 24 macroprocessos e são divididos em três categorias:

- Processos Primários: são os processos finalísticos da organização. Estão relacionados à razão de ser da Companhia, representados na elipse de menor diâmetro da Figura 5.

- Processos de Suporte Intermediário: constituem parte dos processos-meio que detém maior grau de relevância que os processos de apoio pela proximidade com os processos essenciais. Estão relacionados na elipse intermediária da Figura 5.

- Processos de Apoio: constituem a outra parte dos processos-meio. São responsáveis pelo funcionamento dos vários subsistemas da organização, garantindo o suporte adequado aos demais processos. Estão relacionados na elipse mais externa da Figura 5. 


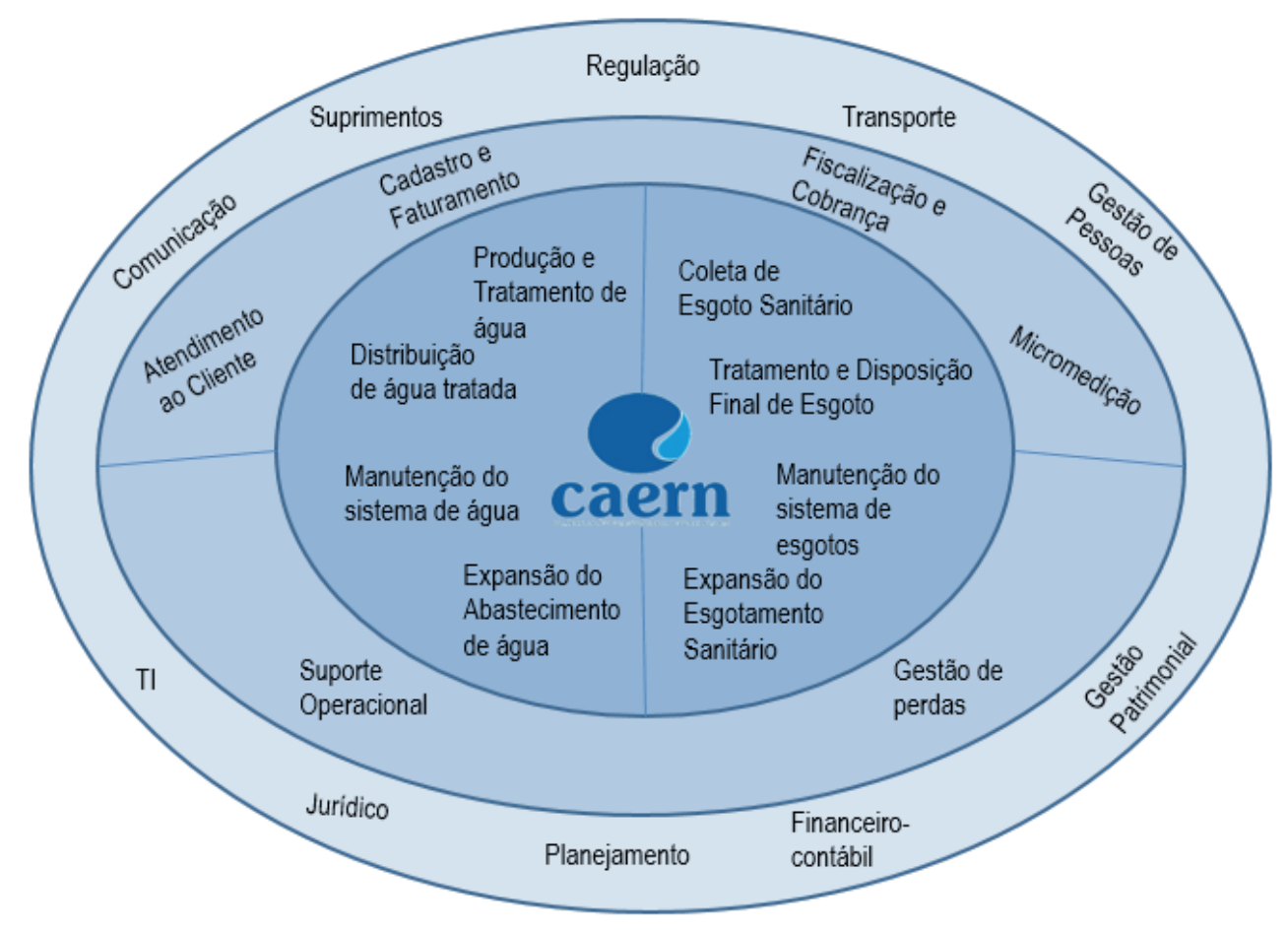

Figura 5 - Macroprocessos da CAERN.

Nota. Fonte: CAERN

\section{3. Área de TI na CAERN}

Na Companhia, a Gerência de Tecnologia da Informação - GTI é o setor responsável pela área de $\mathrm{TI}$, formalmente instituída no regimento interno. A GTI está vinculada à Diretoria de Planejamento e Finanças - DP, que, por sua vez, está subordinada à Presidência. Estão subordinadas à GTI duas unidades administrativas, a Unidade de Desenvolvimento de Sistemas - UDES e a Unidade de Suporte Técnico - USUT. Abaixo, na Figura 6, é apresentado um fragmento do organograma da CAERN que evidencia a posição hierárquica da GTI na organização. 


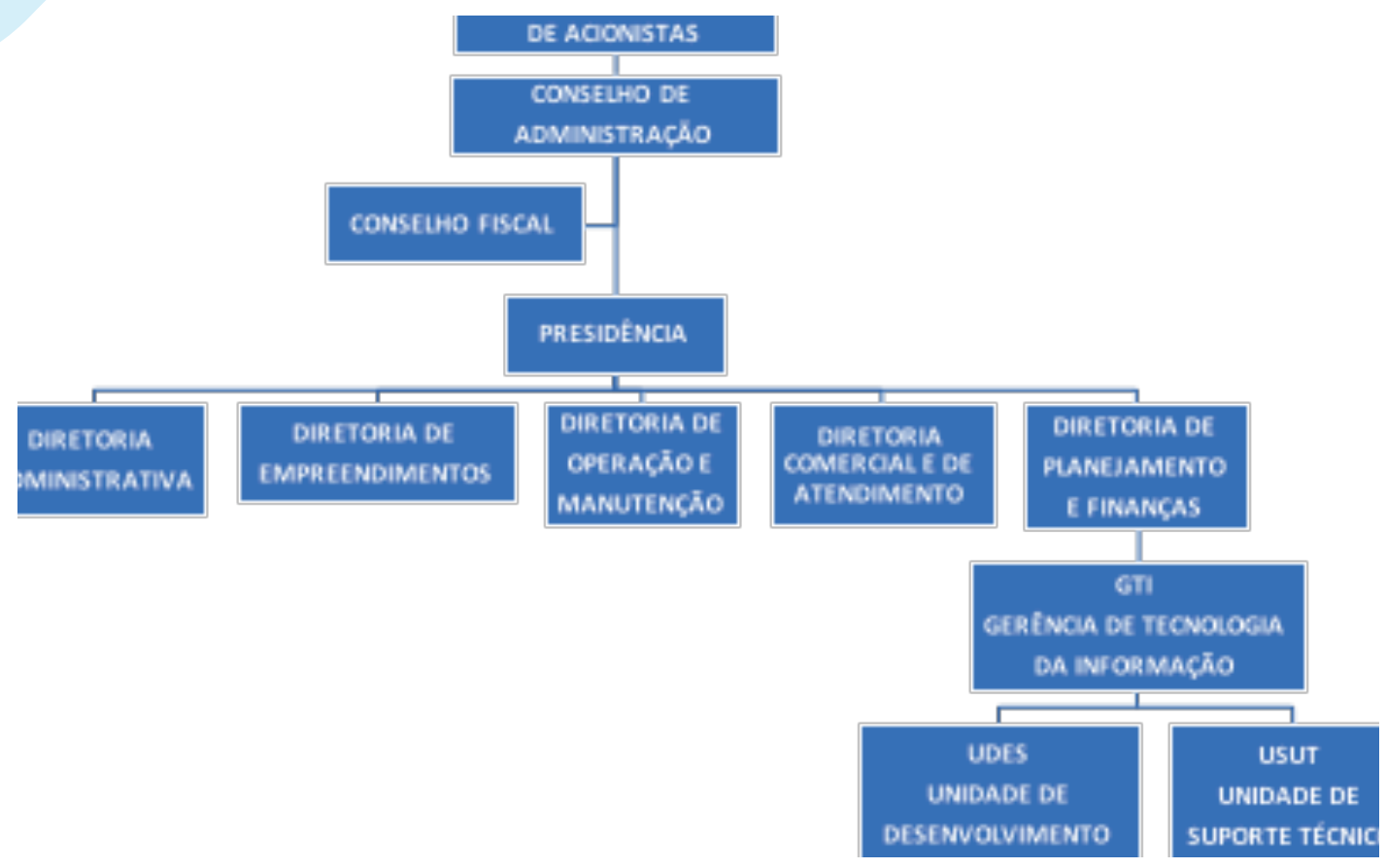

Figura 6 - Organograma da CAERN

Nota. Fonte: CAERN

Na GTI (e suas duas unidades) estão concentradas toda a definição e administração da infraestrutura de datacenter, redes, sistemas, serviço de suporte e aquisições de TI. O quadro funcional é composto pelos cargos: agente administrativo, analista de sistemas, programador de computador, analistas de suporte, técnico de manutenção de computadores e estagiário.

\subsubsection{Gerência de Tecnologia da Informação - GTI}

A Gerência de Tecnologia da Informação é a unidade administrativa responsável pelo planejamento, coordenação e controle das atividades de desenvolvimento de sistemas e suporte técnico que envolve a Tecnologia da Informação inerente à Companhia.

É o principal canal consultivo de TI para a direção da companhia, sendo o elo entre as demandas da organização e as unidades de TI. É, também, o responsável pela gestão dos contratos, planejamento orçamentário e pelo planejamento estratégico de TI.

A CAERN ainda não possui um PETI (Planejamento Estratégico de TI), nem PDTI (Plano Diretor de TI). O alinhamento da TI com a estratégia da companhia é através de projetos incluídos no planejamento estratégico da organização.

O papel da TI ainda é pouco compreendido pela organização, variando sua relevância de acordo com a diretoria vigente, o que traz grande risco de descontinuidade de trabalhos importantes. Assim, estruturas de tomada de decisão não estão bem definidas, os processos de alinhamento são insuficientes e as abordagens de comunicação são escassas.

\subsubsection{Unidade de Suporte Técnico - USUT}

O regimento interno da CAERN, define a Unidade de Suporte Técnico como sendo a unidade 
administrativa que coordena as atividades de manutenção dos ativos de informática, manutenção do cadastro de usuários e administração dos equipamentos centrais de Processamento de dados. É através dela que é administrada toda a infraestrutura de TI da CAERN.

A infraestrutura de $\mathrm{Tl}$, resumidamente, é formada por três servidores físicos, diversos servidores virtuais, aproximadamente 1.100 (um mil e cem) computadores, aproximadamente 100 impressoras/ multifuncionais e rede de dados corporativa que interliga todas as unidades administrativas (em todo o RN), através de links dedicados e composta por quase uma centena de ativos de redes. A USUT ainda gerencia, aproximadamente, 400 licenças de softwares entre sistemas operacionais, ERP, banco de dados, virtualização, segurança, sistema de pacotes para escritório e softwares de engenharia.

A USUT tem duas naturezas de serviços. Uma é realizada pelos analistas de suporte e é voltada para o monitoramento dos sistemas, da infraestrutura de datacenter e das redes, identificando novas tecnologias e aplicando ajustes e configurações necessárias à melhoria do desempenho, expansão das capacidades de processamento, armazenamento, melhorias dos mecanismos de segurança, elaboração de laudos técnicos e monitoramento. Este serviço exige do coordenador o envolvimento direto nos processos de aquisições de TI, projetos e atualização tecnológica.

A outra natureza, executada pelos técnicos de manutenção de computadores, é voltada ao suporte e atendimento técnico ao usuário. Para conseguir atender todas as regionais, exige-se grande esforço do coordenador voltado para logística, padronização dos procedimentos, monitoramento dos chamados e comunicação constantes entre os integrantes, já que os técnicos estão divididos em equipes distribuídas em seis regiões.

Observa-se que na USUT as duas naturezas de atividades exigem grande esforço de coordenação em focos diferentes, o que pode demandar mudanças estruturais.

Os contratos de TI na USUT são bem fiscalizados, principalmente após a definição formal dos fiscais de contrato mediante portaria e apoio da direção.

Quanto à prestação de seus serviços, a USUT não possui definição do seu catálogo de serviços, indicadores de desempenho e nem SLA (Service Level Agreement).

\subsubsection{Unidade de Desenvolvimento de Sistemas}

Conforme o regimento interno da CAERN, a Unidade de Desenvolvimento de Sistemas - UDES é a unidade administrativa que coordena a criação, manutenção e adoção de software aplicativo em uso pelos demais setores da Companhia.

Atualmente, a UDES possui 07 (sete) analistas de sistemas e 01 (um) programador. Estas pessoas são responsáveis por atender todas as demandas de sistemas da Companhia, compreendendo 42 (quarenta e dois) sistemas em uso, distribuídos em três grupos, Sistema Comercial (Sistema Integrado de Gestão de Serviços de Saneamento - GSAN), ERP (Protheus TOTVS) e os sistemas desenvolvidos pela própria equipe, chamado de Sistemas Internos.

Cada um dos sistemas existentes demanda suporte ao usuário e sustentação, ou seja, de manutenção que pode ser corretiva (correção de erros) ou evolutiva (novas funcionalidades, mudanças de regras, 
melhorias etc.). Para isso é necessário, por parte do analista de sistemas, entender a tecnologia utilizada, os códigos fontes (como o sistema está escrito) e o próprio negócio, ou seja, as regras definidas pelas áreas detentoras dos processos de negócio que ditam o comportamento do sistema.

Todas as equipes utilizam uma ferramenta de registro de chamados para comunicação com os clientes internos, por meio do qual o coordenador pode acompanhar as demandas.

Para os sistemas desenvolvidos internamente, a equipe responsável padronizou seu processo de desenvolvimento, adotando uma simplificação do processo do RUP (Rational Unified Process) e estabeleceu um padrão de arquitetura de sistema, entretanto, o processo ainda não é plenamente seguido.

$O$ ERP é mantido por equipe interna e por equipe terceirizada. A equipe interna não utiliza qualquer processo formal, dificultando a gestão das atividades, gestão da configuração e do conhecimento. A equipe terceirizada atua sob demanda, quando solicitada pela UDES. Devido à grande demanda do setor e à quantidade de funcionários insuficiente para seu atendimento, muitas vezes a equipe terceirizada atua diretamente com os clientes internos da UDES (demais setores da CAERN), sem a supervisão dos fiscais, dificultando o acompanhamento de suas atividades e a medição e fiscalização do contrato.

A equipe que lida com o GSAN atua na comunicação com o cliente interno (principalmente a área comercial), dando suporte, desenvolvendo relatórios e levantando requisitos e sugerindo soluções. As demandas corretivas e evolutivas são repassadas para a fábrica de software. Há um processo de requisição e entrega de manutenções evolutivas definido no contrato, porém é pouco fiscalizado, principalmente devido às cláusulas contratuais mal definidas.

Os processos desempenhados pelas equipes da UDES não possuem SLA's definidos, nem catálogo de serviços ou indicadores de desempenho e os contratos são pouco fiscalizados.

\section{ANÁLISE E INTERPRETAÇÃO DOS RESULTADOS}

Weill e Ross (2006) elaboraram um questionário que serve de ponto de partida para a formulação da governança, contendo uma série de perguntas representativas de cada decisão de TI. O presente trabalho utilizou este questionário como guia para identificar o modelo de governança atual da CAERN, através da avaliação junto à Gerencia de TI da companhia. A seguir serão apresentadas as respostas obtidas que permitem uma visão estratégica quanto aos Princípios de TI, Arquitetura de TI, Infraestrutura de TI, e Priorização e Investimento.

\subsection{Princípios de TI}

Os princípios de TI são decisões de alto nível sobre como a TI é utilizada no negócio. Eles são consequência dos princípios de negócio estabelecidos para a organização e estabelecem uma postura organizacional que pode ser traduzida em políticas, normas e diretrizes específicas. Desta forma, os princípios de TI estabelecem os requisitos de padronização e integração de processos numa organização. 


\section{ISSN - 2447-178X}

- Como os princípios do negócio se traduzem nos princípios de TI para guiar as tomadas de decisão sobre TI?

Os princípios de negócio não estão claros para a área de TI, o que se compreende são a missão, visão e os objetivos estratégicos do planejamento estratégico da CAERN. O planejamento é baseado na metodologia do BSC, onde são definidos projetos que devem estar alinhados aos objetivos estratégicos. Entre eles estão alguns dos projetos coordenados pela TI ou com a participação dela.

\section{- Qual é o papel da TI no negócio?}

Para o negócio da CAERN a TI tem papel fundamental, pois praticamente todos os processos comerciais e grande parte dos processos administrativos são operacionalizados via sistema de informação. Além disso, devido à grande capilaridade da companhia, com atuação em mais de 150 municípios do RN, exige uma estrutura eficiente de comunicação, de suporte técnico e de integração das informações. Porém, a percepção do papel da TI para a alta direção é limitada e varia de acordo com a direção vigente, que muda a cada mandato do governo estadual.

\section{- Quais são os comportamentos desejáveis de TI?}

A Gerência de Tl estabeleceu, informalmente, os seguintes princípios de TI ou comportamentos desejáveis:

- Se o cliente não está recebendo adequadamente os serviços da CAERN, que não seja por interrupção dos serviços de Tl;

- Integrar sistemas sempre que possível;

- Reutilizar antes de adquirir. Adquirir antes de desenvolver;

- Ser mais analista de negócio do que desenvolvedor (este princípio não é bem aceito pelos desenvolvedores);

- Evitar, ao máximo, projetos em cuja área solicitante não demonstra engajamento, domínio das informações e dos processos.

- Manter a arquitetura padronizada;

A informalidade provoca baixa percepção e alguns desvios de comportamentos acontecem, onde a atuação do gerente de ti se dá de forma corretiva.

\section{Como é "financiada" a TI?}

Os gastos com TI fazem parte do orçamento anual, que é aprovado pela Diretoria Colegiada durante o planejamento orçamentário anual da Companhia. No planejamento são considerados os gastos operacionais e os investimentos. A maioria dos investimentos fazem parte dos projetos estratégicos. Porém, algumas vezes, a companhia demanda soluções que não estavam planejadas ou cuja necessidade a própria área de TI não previu, mas que precisam ser atendidas. Nestas 


\section{ISSN - 2447-178X}

ocasiões, a Diretoria de Planejamento e Finanças pode aprovar o remanejamento de recursos entre as metas orçamentárias. Além disso, na CAERN, não é aplicada um processo de verificação para avaliar o retorno de investimento ou valor que a TI gera para o negócio.

Algumas políticas de TI foram formalizadas através de normas de diretorias. A cada norma lançada é feito um trabalho de divulgação, através de matéria elaborada pelo Assessoria de Comunicação Social, responsável por administrar o conteúdo da Intranet e Portal da CAERN. Todas as normas e resoluções da companhia também estão disponíveis em seção específica da Intranet. Ocorre, porém, que mesmo sendo definidas em norma e aprovadas pela diretoria colegiada, algumas regras são desobedecidas por alguns setores que usam de sua influência com algum diretor para não cumprir as regras, gerando conflitos de interesses.

Apesar da área de TI estabelecer regras e políticas, a formalização destas só é possível por meio de aprovação da Diretoria Colegiada, caracterizando este processo decisório sobre os princípios de TI como Duopólio de TI.

\subsection{Arquitetura de TI}

A arquitetura de TI é o conjunto integrado de escolhas técnicas para guiar a organização na satisfação das necessidades do negócio. Deve prover a padronização e a integração técnicas e de negócio desejadas. A padronização de processos e dados são suas principais características.

- Quais são os principais processos do negócio? Como eles se relacionam?

O negócio da CAERN é baseado nos processos de abastecimento de água e esgotamento sanitário, sendo os principais:

\section{- Abastecimento de Água:}

- Produção e tratamento de água: a água é captada em um manancial (lagoa, poço, etc.), é transportada para uma estação de tratamento para torná-la potável, pronta para ser distribuída para o consumidor;

- Distribuição de água tratada: A água percorre um conjunto de estruturas de rede hidráulica, compreendida por reservatórios, tubulações, bombas de reforço de pressão, ramais e por fim chegar até a casa do consumidor;

- Manutenção do sistema de água: Paralelo aos demais processos de abastecimento de água, ocorre o processo de manutenção do sistema, a fim de evitar interrupções ao abastecimento da população;

- Expansão do abastecimento de água: conforme a população vai aumentando, o consumo de água também aumenta, exigindo ampliação da capacidade de abastecimento de água.

\section{- Esgotamento Sanitário:}

- Coleta de esgoto sanitário: Depois do uso da água, seja no banho, na 
limpeza de roupas ou na descarga do vaso sanitário, o esgoto começa a ser formado. Os esgotos residenciais e industriais são enviados para a rede coletora de esgoto, conduzindo-o a uma estação de tratamento de esgoto.

- Tratamento e disposição final do esgoto: ao chegar na estação de tratamento, o esgoto passa por processos específicos que tornam possível devolver a água, em boas condições, ao meio ambiente, ou reutilizá-la para fins não potáveis.

- Manutenção do sistema de esgoto: Paralelo aos demais processos de esgotamento sanitário, ocorre o processo de manutenção preventiva e corretiva, a fim de evitar danos à população e ao meio ambiente;

- Expansão do esgotamento sanitário: conforme a população vai aumentando, a geração de esgoto também aumenta, exigindo ampliação da capacidade da coleta e tratamento de esgoto.

Paradoxalmente, os processos primários são os menos normatizados dentro da companhia, assim, muitos conceitos, procedimentos e indicadores não são bem definidos, o que reflete na baixa utilização de soluções de TI e na falta de padronização das soluções de automação. Dessa forma, outras áreas com maior maturidade sobre seus processos acabaram recebendo maiores investimentos em TI. Exemplos disso são os processos das áreas comercial e administrativo-financeira.

Considerando o baixo nível de maturidade dos processos primários, os processos de suporte intermediários, voltados à geração de receita, ocupam a posição dos processos principais da empresa. Neste grupo estão os processos da área comercial:

a. Atendimento ao cliente: processo de recepção das demandas dos clientes presencial, por telefone ou sistema web. Os principais atendimentos estão relacionados à pedidos de ligações, de corte e religação; negociação de débitos; mudança de titularidade; relatar vazamentos e cobranças indevidas; solicitação de retificação de leituras.

b. Cadastro: processos voltados para a manutenção do cadastro de clientes, imóveis, tarifas, ligações de água e de esgoto, categorização de clientes, cadastro de hidrômetros.

c. Micromedição: medição de hidrômetros dos clientes em campo ou por telemetria para emissão de faturas;

d. Faturamento: emissão de faturas com base nas leituras e categorias de clientes.

e. Cobrança: cobrança de débitos dos clientes através de avisos, de emissão de ordem de serviços para corte da ligação e da negativação de clientes.

f. Fiscalização: verificação e notificação de clientes por irregularidades nas ligações.

- Que informação "dirige" esses processos principais? Como esses dados devem ser integrados? Os processos principais são dirigidos pelas informações do consumidor, faturamento e 


\section{ISSN - 2447-178X}

arrecadação. Todas essas informações estão no banco de dados do sistema comercial, havendo pontos de integração com outras bases de dados (ERP e Sistemas Internos) através de troca de arquivos ou por uma interface de troca de mensagens (web services).

- Quais capacidades técnicas devem ser padronizadas na empresa para permitir o uso eficiente da Tl e facilitar a padronização e a integração dos processos?

Para uso mais eficiente da Tl, é necessário padronizar as tecnologias e metodologias utilizadas pelas equipes de TI. Capacidade de compreensão dos pontos de integração entre sistemas (conhecimento das informações, dos modelos de dados e do negócio), atender novas demandas, quando possível, expandindo os sistemas existentes e maior utilização da ferramenta de $\mathrm{Bl}$, tanto pela TI quanto pelas áreas de negócio.

- Quais atividades devem ser padronizadas na empresa para permitir a integração dos dados? A adoção de soluções de TI deve ser coordenada pela GTI, evitando soluções isoladas dentro da companhia. Aplicações desenvolvidas internamente devem prever necessidades de integração, evitando duplicação de dados. Padronizar as tecnologias, modelos de dados e de integração de informações.

As decisões sobre a Arquitetura de TI são centralizadas na própria área de TI, configurando uma Monarquia de TI, porém não há uma estrutura formal e as decisões não seguem uma estrutura rígida.

\subsection{INFRAESTRUTURA DE TI}

A infraestrutura de TI é a base da capacidade planejada de TI (tanto técnica quanto humana) disponível em todo o negócio. Engloba os serviços de TI compartilhados para prover a capacidade da TI tipicamente antes que as necessidades sejam conhecidas exatamente. Os serviços de infraestrutura incluem: serviços de rede de telecomunicação; provisão e gerenciamento de computadores em larga escala (servidores da rede); gerenciamento da base de dados compartilhada; expertise em pesquisa e desenvolvimento para identificar a utilidade de tecnologias emergentes para o negócio; e uma intranet para toda a organização. Determinar onde os serviços locais de infraestrutura devem ser posicionados, quando devem ser atualizados e a conveniência de terceirizá-los são decisões essenciais de infraestrutura.

- Quais serviços de infraestrutura de TI são mais críticos para atingir os objetivos estratégicos da companhia?

O sistema comercial (arrecadação, faturamento, micromedição, renegociação de débitos, emissão de contas, etc) e ERP (contabilidade, financeiro, contrato, estoque, recursos humanos, etc.) são os mais críticos, principalmente porque a sua interrupção gera prejuízos financeiros e interferem no atendimento de clientes e fornecedores. Assim como a Internet, também é um item crítico para algumas áreas, como o setor jurídico, que tem prazos para envio de processos aos tribunais.

Dessa forma, são críticos: Segurança da Informação, Sistemas de Informação prioritários, 


\section{ISSN - 2447-178X}

Redes (conectividade entre todos os pontos de presença), Servidores, Bancos de dados, Storages e Backup.

- Quais serviços de infraestrutura devem ser implantados na empresa e quais os requisitos de nível de serviços correspondentes seriam desejáveis?

O datacenter da Caern está sendo migrado para uma sala cofre do Estado do RN, necessitando um site backup. Não há definição dos requisitos dos níveis de serviço, nem plano de continuidade do negócio.

- Qual o plano para manter atualizada a infraestrutura de TI na empresa?

Não há um plano formal de atualização da infraestrutura. 0 que há são projetos iniciados quando são detectadas necessidade de atualização. Há, no entanto, um processo de monitoramento constante dos servidores do datacenter, em que o sistema coleta informações das capacidades utilizadas nos servidores (memória, armazenamento, processamento, etc.) e informa a necessidade de alocar mais ou menos recursos para a demanda atual. Além disso, prevê a tendência de consumo desses recursos ao longo do tempo. Isso permite à equipe de infraestrutura prever a necessidade de atualização desses equipamentos.

Há também um certo consenso sobre a renovação do parque tecnológico: Para os computadores e impressoras, o parque é renovado a cada fim de contrato, normalmente a cada quatro anos. Para os ativos do datacenter, as aquisições são feitas com garantia estendida até o fim da sua vida útil esperada. Quando os equipamentos se tornam defasados, este são utilizados em ambientes menos críticos e novos equipamentos são adquiridos. Espera-se que à medida que os equipamentos se tornam defasados, os sistemas possam ser migrados para a nuvem.

\section{- Quais serviços de infraestrutura deveriam ser terceirizados?}

Atualmente, há outsourcing de impressão, computadores e links de dados. A área de $\mathrm{TI}$, não enxerga outros pontos de terceirização a curto prazo. Para o futuro, a ideia é iniciar a migração dos serviços para a nuvem.

$\mathrm{Na}$ CAERN as decisões sobre infraestrutura de TI são tomadas pela equipe de Tl, caracterizando uma Monarquia de TI. Porém, ainda não há um normativo que instrua as demais áreas da empresa a submeterem seus projetos à área de TI para avaliação das necessidades de infraestrutura. Assim, é comum a execução de projetos de outros setores da companhia, como, por exemplo, a construção de um novo escritório, sem previsão de qualquer infraestrutura de TI (instalações de rede, link de dados, computadores, impressoras, etc.). Outro exemplo de não inclusão da Tl em decisões importantes é quanto à contratação de pessoas sem consultar área de TI sobre a disponibilidade de uma estação de trabalho.

\subsection{Necessidade de Aplicação de Negócio}

As necessidades de aplicações de negócio são os requisitos do negócio para compra ou 
desenvolvimento interno de aplicações. Embora as demais decisões de TI envolvam o valor de negócio da TI, são as decisões referentes às necessidades do negócio específicas que geram valor diretamente. A identificação da necessidade de negócios de aplicações de Tl costuma ter dois objetivos conflitantes: a criatividade e a disciplina.

\section{- Quais as oportunidades do negócio para novas aplicações?}

Aplicações de Bl e Big Data; Utilização de Aplicativos Móveis e Virtualização dos processos.

- Como são atendidas as necessidades do negócio dentro dos padrões de arquitetura? Quando uma necessidade de negócio justifica uma exceção aos padrões?

O padrão arquitetural é um conjunto de três modelos distintos: o ERP, o GSAN, e os Sistemas Internos. As necessidades são analisadas pela equipe da Unidade de Desenvolvimento de Sistemas e tenta encaixá-la em um dos três modelos. Caso a demanda esteja relacionada com a finalidade do GSAN, esta poderá ser incorporada a ele. Caso a demanda possa ser atendida pelo ERP, então o módulo relacionado será implantado ou uma nova funcionalidade é acrescida a ele. Em último caso, se não for possível a aquisição de uma solução pronta, então o sistema será desenvolvido conforme o padrão tecnológico estabelecido. Caso a arquitetura atual não atenda, as decisões de exceção são tomadas pela equipe de desenvolvimento de sistemas, mas não há um processo formal para isso, o que provoca, às vezes, decisões individuais. As demandas por sistemas surgem de todas as partes. No geral, as áreas de negócio repassam a demanda à sua diretoria que encaminha à GTI. Estas demandas são analisadas quanto à viabilidade e apresenta parecer à Diretoria de Planejamento e Finanças DP. As demandas são acordadas com as áreas e estas apresentam como proposta de projeto ao planejamento orçamentário e estratégico para próximo exercício. Para os casos onde há conflitos de interesse entre as diretorias, a DP negocia com as diretorias envolvidas em busca de um consenso sobre a rejeição, adiamento ou aprovação do projeto. Isso também acontece para os casos onde a GTI considera o projeto inviável. Não necessariamente a priorização dos projetos estão ligados, de fato, aos objetivos estratégicos, muitas vezes é apenas uma decisão política. Algumas demandas não são inseridas no Planejamento Estratégico da CAERN, mas entram no planejamento anual da GTI.

- Quem é responsável pelos resultados de cada projeto e pela institucionalização das mudanças organizacionais para assegurar o valor proporcionado?

O responsável pelo resultado do projeto e institucionalização é a própria área demandante da solução. Porém, algumas vezes, são demandas originadas nas diretorias e as áreas de negócio não se engajam suficientemente. Nestes casos é comum tentarem transferir a responsabilidade pelos resultados do projeto para a área de TI. Mesmo projetos com o apoio constante de uma diretoria podem sofrer dificuldades quando há conflitos de interesse. 0 instrumento de institucionalização é via norma de diretoria colegiada. Muito projetos de TI não possuem gerentes de projetos ou segue alguma metodologia de gestão, assim muitos projetos não atingem seus objetivos, não cumprem prazo e/ou custos. 


\section{ISSN - 2447-178X}

Em resumo, as necessidades de aplicação de negócio são originadas pelas áreas de negócio e são avaliadas pela GTI, porém, a tomada de decisão só utiliza um mecanismo formal de aprovação quando se torna um projeto estratégico. Nesta situação, a decisão é tomada pela diretoria colegiada. Para os demais casos, as decisões são tomadas em acordo entre a TI, Diretoria de Planejamento e área de negócio. Dessa forma, o arquétipo mais próximo seria o federalismo, embora não haja um processo formal que dita as regras de aceitação e priorização quanto às necessidades de aplicação.

\subsection{Priorização e Investimento de TI}

Investimentos e priorização de $\mathrm{Tl}$ envolvem decisões sobre o quanto e onde investir em $\mathrm{Tl}$, incluindo aprovação de projetos e técnicas de justificativa. A decisão sobre investimentos em Tl é a mais visível e controversa das decisões-chave de TI e envolve: a) quanto gastar; b) em que gastar; c) como conciliar as necessidades de diferentes grupos de interesse.

- Que mudanças nos processos ou melhorias são estrategicamente mais importantes para a CAERN?

Os processos de Gestão das mais diversas áreas da companhia, utilizando BI, tem grande potencial de trazer resultados positivos, além disso, a grande maioria dos processos operacionais trabalham de forma manual, sendo urgente a adoção de soluções informatizadas.

- Qual é o portfólio atual de TI? Esse portfólio é consistente com os objetivos estratégicos da CAERN?

Desenvolvimento e Manutenção de Sistemas de Informação; Contratações de Tl; Administração da Infraestrutura de TI (incluindo rede local, servidores, storage, banco de dados corporativo, conectividade com a internet, conectividade com todos municípios onde a escritório da CAERN); Segurança da Informação; Portal da CAERN na Internet; Intranet Corporativa; Service Desk.

Anualmente a CAERN realiza seu planejamento orçamentário, onde cada área, inclusive a de $\mathrm{Tl}$, informa suas necessidades de recursos financeiros para manter a continuidade dos contratos vigentes $\mathrm{e}$ de investimentos. 0 orçamento total da CAERN tem um teto pré-estabelecido que direciona uma série de rodadas de ajustes, até que o orçamento seja aprovado pela diretoria colegiada e, por fim, homologado pelo conselho de administração. Os valores disponibilizados (aos setores) são categorizados por metas. Em etapa posterior, é realizada a definição dos projetos que entrarão no planejamento estratégico. Para aprovação de um projeto estratégico que exige recursos financeiros, é obrigatória a existência previsão no planejamento orçamentário.

A definição das necessidades de investimento em TI é elaborada pela GTI e discutida em conjunto com a DP que analisa e prioriza os investimentos que juga necessários. Nas discussões com a TI, a DP pode recusar itens e incluir outros investimentos demandados por outras áreas, esta etapa inicial de priorização. Após discutido e acordado com a TI, a proposta é submetida à diretoria colegiada, onde a DP defende a necessidade daqueles investimentos perante a diretoria colegiada. As rodadas de ajustes do orçamento priorizam os itens e o que couber no orçamento são contemplados com recursos financeiros. 
Quanto ao portfólio de projetos de $\mathrm{Tl}$, a estimativa de retorno sobre o investimento é medida, no geral, qualitativamente. Para os projetos priorizados não há uma obrigatoriedade de demonstrar se os resultados esperados foram atingidos.

Como a decisão sobre a priorização e investimento de TI conta com a participação da GTI e Diretoria Colegiada, configurando o estilo Duopólio de TI.

\subsection{Matriz de Arranjo de Governança de TI da CAERN}

A partir da análise dos resultados do questionário apresentado na seção anterior, foi possível montar a Matriz de Arranjos de Governança e identificar a estrutura de tomada de decisões da CAERN. A Matriz de Arranjos de Governança, apresentada na Tabela 1, fornece um mapa do arranjo decisório da Governança de TI utilizado pela companhia.

Tabela 1:

Matriz de Arranjo de Governança de TI da CAERN

\begin{tabular}{llllll} 
Decisão Chave & Princípios & Arquitetura \\
Temador da Decisão & de TI & $\begin{array}{l}\text { Estratégia de } \\
\text { Infraestrutura } \\
\text { de TI }\end{array}$ & $\begin{array}{l}\text { Necessidades } \\
\text { de aplicações de } \\
\text { negócio }\end{array}$ & $\begin{array}{l}\text { Investimento } \\
\text { e priorização } \\
\text { de } \mathrm{TI}\end{array}$ \\
\hline
\end{tabular}

Monarquia de negócio

- os altos gerentes (Diretoria)

\begin{tabular}{lll}
\hline $\begin{array}{l}\text { Monarquia de TI - os } \\
\text { especialistas em TI } \\
\text { (Gerência de TI) }\end{array}$ & $\begin{array}{l}\text { Área de TI (GTI, } \\
\text { UDES e USUT) }\end{array}$ & $\begin{array}{l}\text { Área de TI (GTI, } \\
\text { UDES e USUT) }\end{array}$ \\
\hline $\begin{array}{l}\text { Feudalismo - cada unidade } \\
\text { de negócio (Gerência) toma } \\
\text { decisão independente }\end{array}$ & & \\
\hline $\begin{array}{l}\text { Federalismo - combinação } \\
\text { entre centro corporativo }\end{array}$ & Área de TI (GTI, \\
$\begin{array}{l}\text { (Diretoria) e as unidades } \\
\text { de negócio (Gerência), com } \\
\text { ou sem envolvimento do } \\
\text { pessoal de TI }\end{array}$ & UDES e USUT), \\
\hline $\begin{array}{l}\text { Duopólio de TI - Grupo de } \\
\text { TI e Diretoria ou Grupo de } \\
\text { TI e Unidade de Negócio }\end{array}$ & Área de TI (GTI, & Negócio e Diretoria \\
(Gerência) & e Diretoria & Colegiada \\
& Colegiada & \\
\hline $\begin{array}{l}\text { Anarquia - Decisão } \\
\text { individual ou por pequenos } \\
\text { grupos }\end{array}$ & Colegiada & Área de TI (GTI, \\
\hline
\end{tabular}

Não sabe

Nota. Fonte: Dados da pesquisa (2017) 
As células da Matriz apresentam os tomadores de decisão, indicando como é estabelecido cada um dos arranjos da Governança de TI da CAERN. As células destacadas (cor verde) correspondem à um dos arranjos com melhores desempenho (ver Figura 2), demonstrando, em princípio, um resultado satisfatório para a governança de TI da CAERN, porém cabe analisar a utilização de estruturas de tomada de decisão, processos de alinhamento e abordagens de comunicação que favoreçam a governança.

Como apresentado, os princípios de TI não estão formalmente definidos na CAERN. Para Mendonça (2015) estes princípios são declarações de alto nível sobre como a TI é utilizada no negócio, que podem ser discutidas, debatidas, apoiadas, recusadas e aprimoradas, tornando-se parte do ambiente organizacional e definindo comportamento desejável tanto para os profissionais de TI como para os usuários da tecnologia da informação. Conclui-se que a informalidade dos princípios dificulta a compreensão das partes quanto aos direcionamentos estratégicos sobre a TI em relação ao negócio e, neste ponto, Weill e Ross (2006) afirmam que: "como os princípios direcionam todas as decisões de TI, quaisquer equívocos em relação aos princípios limitam a eficácia de outras quatro decisões".

$\mathrm{O}$ arquétipo identificado para as decisões sobre os Princípios de TI na CAERN foi o Duopólio de TI. Para Gonçalves et al. (2009) que afirma que a escolha da tecnologia mais adequada depende do nível de compreensão das estratégias implantadas pela empresa e das suas respectivas consequências sobre as variáveis estratégicas. Mendonça (2015) conclui que a maior participação da área de negócio nas decisões que envolvem princípios da TI pode ser um fator relevante, pois pode contribuir para essa compreensão. Mendonça (2015) cita, ainda, Albertin e Albertin (2010) que afirmam que essas decisões de alto nível compartilhadas entre os altos executivos e os especialistas de TI, permitem focar a TI elemento estratégico para o negócio.

Recomenda-se, portanto, que duopólio de TI existente na companhia atue na definição dos princípios de $\mathrm{Tl}$, baseados nos princípios e estratégias de negócio, tornando-os claros e formais na instituição.

Quanto à forma de financiamento da TI, a CAERN apresenta estrutura bem definida de planejamento orçamentário que, de forma positiva, promove o poder de decisão através do duopólio de TI. Cabe ressaltar, porém, que não há uma regra ou uma política que determina como as TI será financiada para atender as diversas áreas da companhia, bem como não há um planejamento estratégico de TI (PETI) que direcione a direcione em médio ou longo prazo.

$\mathrm{Na}$ CAERN, as decisões sobre arquitetura de TI são tomadas através de Monopólio de TI o que sugere consonância com os resultados das pesquisas realizadas por Weill e Ross (2006), Mendonça et al. (2013) e Mendonça e Sousa Neto (2012), na qual arquétipo Monarquia de TI foi predominante, com percentuais entre 72 e 73\%, como afirma Mendonça (2015). Na pratica, a CAERN apresenta três arquiteturas de sistemas com níveis satisfatórios de integração entre eles, o que reforça a tecnicidade exigida dos especialistas de TI para as decisões sobre arquitetura. No entanto, não há um mecanismo formal para orientação e direcionamento da arquitetura, muito menos para arbitrar sobre as exceções. Considerando o porte da empresa que é a CAERN, que atende a mais de 800 mil consumidores no RN, é importantíssimo pensar em uma arquitetura robusta, integrada e escalável que ofereça segurança e, 
ao mesmo tempo, flexibilidade para o negócio. Assim, neste sentido, faz-se necessária a criação de um Comitê de Arquitetura de TI que, tipicamente é composto por especialistas técnicos, e tem o objetivo de definir normas e, em alguns casos, conceder exceções. Segundo Weill e Ross (2006), na maioria dos casos, o papel do comitê de arquitetura é aconselhar a equipe de liderança de TI sobre questões de arquitetura, mas, ocasionalmente, é um órgão chave de tomada de decisões de governança.

Além do comitê de arquitetura, é importante a definição de um processo para tratar das exceções à arquitetura quando os padrões arquiteturais existentes na empresa forem considerados obsoletos ou não atenderem às necessidades de negócio.

As decisões sobre Infraestrutura de TI na CAERN são tomadas em Monopólio de TI, harmonizando com dois dos três arranjos de sucesso apresentados na figura 2. Porém, não há uma enumeração dos serviços disponíveis, dos níveis alternativos de qualidade e respectivos custos, ou seja, não são aplicados dois importantes processos de alinhamento que são o catálogo de serviços e os Acordos de Nível de Serviços. Esta ausência dificulta operação padronizada dos serviços e a percepção se a infraestrutura de $\mathrm{TI}$ atende aos requisitos das áreas de negócio. $\mathrm{O}$ fato mais crítico é a ausência de um plano de continuidade do negócio, o que expões a companhia a sérios riscos de descontinuidade de atividades fundamentais.

As decisões sobre necessidade de aplicação se dão de forma aproximada ao federalismo, com a participação das áreas de negócio, diretoria e TI, podendo, algumas vezes, se unilateralmente por uma das Diretorias. As decisões unilaterais, apesar de dar agilidade em alguns casos, pode pecar pela falta de visão holística sobre as necessidades da empresa. Neste caso, o atendimento às necessidades de aplicação pode ficar desequilibrado, ou seja, áreas mais próximas do decisor são beneficiadas em detrimento das mais distantes. Assim, recomenda-se a criação de um conselho de Tl, compreendendo executivos de negócio (com representantes das diretorias, das principais áreas de negócio) e da área de TI, formalizando o arquétipo federalista. Segundo Weill e Ross (2006), as estruturas federalistas equilibram abertamente as prioridades da empresa com as das unidades de negócio, podendo provocar contribuições valiosas para as decisões de governança de TI.

Foi identificado que poucos projetos de TI na CAERN são acompanhados seguindo alguma disciplina de gestão de projetos o que torna baixa sua taxa de sucesso. Para Weill e Ross (2016), a qualquer tentativa de mensurar o progresso de implementações e de identificar e corrigir problemas rapidamente aumenta em muito a possibilidade de sucesso da implementação.

Os investimentos e priorização de TI são decididos na CAERN através de Duopólio de TI, o que pode ajudar a esclarecer os objetivos de negócio, incorporar capacidades de TI na formulação da estratégia e focar nas questões de negócio. Neste sentido, Albertin e Albertin (2010) afirmam que decisões com gastos e investimentos devem ser de responsabilidade dos executivos de negócios, com o apoio da área de TI.

Para Weill e Ross (2006), assim como os princípios de ti, as decisões de investimento e priorização são as principais decisões estratégicas dentre as cinco decisões-chave, pois os investimentos estabelecem compromissos e prioridades. No caso da CAERN, mesmo existindo um processo de planejamento orçamentário anual onde decisão é tomada através da diretoria colegiada, ainda não há 


\section{ISSN - 2447-178X}

um processo de aprovação de investimentos em TI cujo objetivo seria assegurar que os investimentos gerem retornos significativos para a empresa em comparação com outras oportunidades alternativas de investimento nem um modelo padronizado de solicitação de aprovação de investimento de TI que poderia utilizar métricas para estimar o Retorno Sobre Investimento (ROI - Return On Investiment), VPL - Valor Presente Líquido e o risco de cada projeto. Para Weill e Ross (2006) sem modelos de investimentos, os tomadores de decisão têm dificuldade em comparar projetos e podem perder oportunidades de gerar valor, fazendo investimentos com benefícios menos assegurados. Ainda sobre os investimentos, Weill e Ross (2006, p. 106) afirmam que:

Grande parte do desafio de criar uma Governança de Ti eficaz decorre da dificuldade de estimar o valor da Tecnologia da Informação. Os tomadores de decisões sobre TI decidem tanto melhor quanto melhor compreendem o valor que a empresa aufere da TI. Rastrear formalmente o valor de negócio da TI aumenta o aprendizado organizacional sobre o valor de iniciativas habilitadas pela Tecnologia da Informação.

Rastrear o valor do negócio significa avaliar se os objetivos após o término do projeto alcançaram seus objetivos isso inclui determinar se as expectativas de redução de custo ou de aumento de receita realmente se materializaram. $\mathrm{Na}$ CAERN não há um processo formal de rastreabilidade de valor da TI para o negócio, o que não deixa claro se os projetos estão atingindo seus objetivos.

Como a CAERN adota a abordagem duopolista para os Princípios de TI e Investimentos e Priorização de TI, cabe verificar a possibilidade de adoção dos dois mecanismos de governança mais populares, segundo Weill e Ross (2006) para a implementação do duopólio que são: os Gerentes de Relacionamento entre negócio e TI e as Equipes de Processos com membros da TI. Os Gerentes de relacionamento exploram a TI em busca do máximo valor de negócio e pressionam por serviços de TI que atendam suas áreas. As equipes de processos trabalham em busca do melhor modelo operacional, adotando a TI para habilitar processos de toda a empresa, estes mecanismos poderiam ser úteis também para atenuar a baixa participação das áreas de negócio nos projetos de TI e na promoção do conhecimento e melhoria sobre seus processos de negócio.

Por fim, para que a CAERN tenha uma governança eficaz recomenda-se também o desenvolvimento de uma estratégia de comunicação para difundir para toda a empresa sobre as formas de decisão, processos de Governança de TI e sobre os respectivos comportamentos desejáveis. Weill e Ross (2006) entendem que quanto mais a administração comunica formalmente a existência de mecanismos de governança, como eles funcionam e quais os resultados esperados, mais eficaz é a governança dentro da organização. 


\section{CONSIDERAÇÕES FINAIS}

O presente trabalho teve como objetivo principal identificar na Companha de Águas e Esgotos do RN a matriz de arranjos de Governança de TI, segundo o modelo proposto por Weill e Ross (2006). Para alcançar esse objetivo foram utilizadas entrevistas individuais semiestruturadas com pessoas de áreas chaves da companhia. As entrevistas semiestruturadas demonstraram ser um meio eficiente para compreender e identificar os principais tomadores das decisões chaves de TI, arquétipos, estruturas de tomada de decisão, processos de alinhamento e abordagens de comunicação. Além disso, foram realizadas reflexões sucintas inferidas pelo conhecimento sobre a bibliografia base.

As entrevistas permitiram, desenhar o a matriz de Governança de TI da CAERN, considerando as cinco decisões chaves: Princípios de TI, Arquitetura de TI, Infraestrutura de TI, Necessidades de aplicações de negócio e Investimentos e priorização da TI, bem como foram avaliados os Processos de Alinhamento e Abordagens de Comunicação, possibilitando identificar como os processos decisórios e arranjos de Governança acontecem na companhia, além identificar as carências e oportunidades de melhoria.

A pesquisa constou inicialmente que a CAERN se enquadra em um dos três modelos de melhor resultado apresentados por Weill e Ross (2006), o que é um aspecto bastante positivo para uma boa Governança de TI. Porém, lacunas relativas às boas práticas de Governança não foram identificadas na organização. Entre elas estão, a falta de formalização dos princípios de TI, o que dificulta a compreensão do papel da TI na organização; a falta de planejamento estratégico de TI (PETI); inexistência de mecanismo formal para lidar com a padronização da arquitetura e processos de exceção; falta de acompanhamento dos resultados dos projetos e do rastreio do valor da TI para o negócio; processo de aprovação de investimento de TI insuficiente para estimar ROI e mesurar riscos dos projetos de Tl; ausência de enumeração dos serviços de TI oferecidos e seus respectivos SLA's; ausência de plano de continuidade do negócio.

$\mathrm{O}$ estudo também identificou que a TI possui uma arquitetura que atende as necessidades do negócio, mas há um desequilíbrio entre às soluções de TI para atendimento das áreas de processos de suporte intermediário e as soluções para atendimento dos processos primários. Esse desequilíbrio pode caracterizar dificuldades de priorização por falta de mecanismos de tomadas de decisão, quanto por baixa maturidade dos processos primários.

A utilização de entrevistas semiestruturadas como base para a pesquisa apresenta uma limitação importante quanto à influência da subjetividade da interpretação do pesquisador, tornando a pesquisa com ênfase qualitativa, assim, com base nestas limitações como proposição pra estudos futuros seria a formulação de questionário que permita medir mais precisamente cada um dos aspectos que envolve a identificação de cada aspecto que compõe a matriz de Governança de TI, seus estruturas de tomada de decisão, processos de alinhamento, abordagens de comunicação e nível de compreensão do que é Governança de TI para diferentes níveis hierárquicos da instituição pesquisada. 


\section{ISSN - 2447-178X}

\section{TRABALHOS FUTUROS}

Para trabalhos futuros, sugere-se, buscar identificar a matriz de arranjos de governança de $\mathrm{Tl}$ em outros órgãos públicos do Estado e fazer um comparativo entre elas. Da mesma forma, outra pesquisa que pode ser desenvolvida é buscar identificar as matrizes de Companhias de Águas e Esgotos de outros Estados.

\section{REFERÊNCIAS}

ALBERTIN, Alberto L.; ALBERTIN, Rosa M. M. Estratégia de governança de tecnologia da informação: estrutura e práticas. Rio de Janeiro: Elsevier, 2010.

ALVES, Erick. Lei das Estatais: Saiba tudo sobre a nova Lei 13303. 2016. Disponível em: <https://www. estrategiaconcursos.com.br/blog/lei-das-estatais-13303/>. Acesso em: 24 jul. 2017.

BERLE, A.; MEANS, G. The Modern Corporation and Private Property. NewYork: Macmillan, 1932.

CESAR, Ana Maria Roux Valentini Coelho. Método do Estudo de Caso (Case Studies) ou Método do Caso (Teaching Cases): Uma análise dos dois métodos no Ensino e Pesquisa em Administração. 2005. 23 f. Monografia (Especialização) - Curso de Administração, Universidade Presbiteriana Mackenzie, São Paulo, 2005. Disponível em: <http://www.mackenzie.br/fileadmin/Graduacao/CCSA/remac/jul_ dez_05/06.pdf>. Acesso em: 20 ago. 2017.

DENZIN, Norman K.; LINCOLN, Yvonna S. (Editores). Handbook of qualitative research. (2 Ed.). Thousand Oaks, Califórnia: Sage Publications. 2000.

GONÇALVES, A. P.; POLO, E. F., CORREA, H. L.; HUBERT, M. The alignment between business and IT strategies. In: 6o CONTECSI - Congresso Internacional de Gestão de Tecnologia e Sistemas de Informação, 2009, São Paulo. Anais... 6o CONTECSI, 2009.

GONÇALVES, Andréa De Paiva. Análise das Relações entre Governança Corporativa e

Governança de Tecnologia da Informação em Organizações Brasileiras. 2012. 132 f.

Tese (Doutorado) - Curso de Faculdade de Economia, Administração e Contabilidade,

Universidade de São Paulo, São Paulo, 2012.

LAKATOS, Eva Maria; MARCONI, Marina de Andrade. METODOLOGIA CIENTIFICA. 6. ed. Rio de Janeiro: Atlas, 2011.

LUNARDI, Guilherme Lerch; BECKER, João Luiz; MACADA, Antônio Carlos Gastaud. Um estudo empírico do impacto da governança de TI no desempenho organizacional. Prod., São Paulo, v. 22, n. 3, 2012. Disponível em <http://www.scielo.br/scielo.php?script=sci_arttext\&pid=S0103- 


\section{ISSN - 2447-178X}

65132012000300019\&lng=en\&nrm=iso >. Acessado em: 29 ago. 2017.

MAHONEY, J. The Importance of Integrated Business and Technology Decision Making Will Grow by 2012. Gartner Research, January 2007. Disponível em <http://www.gartner.com/DisplayDocument?doc_ cd=144371 >. Acesso em: 12 jul 2017.

MENDONCA, C. M. C.; SOUSA NETO, M. V. O Perfil do Chief Information Officer (CIO) e a sua Percepção com relação aos arranjos de Governança de TI. Revista de Economia e Administração (Impresso), v. 11, p. 250-272, 2012.

MENDONCA, Cláudio Márcio Campos de et al. Governança de tecnologia da informação: um estudo do processo decisório em organizações públicas e privadas. Rev. Adm. Pública, Rio de Janeiro, v. 47, n. 2, abr. 2013. Disponível em: <http://dx.doi.org/10.1590/S0034-76122013000200008 >. Acesso em: 29 ago. 2017.

MENDONÇA, Cláudio Márcio Campos de. Serviço de nuvem pública e sua relação com os arranjos de governança de ti e o alinhamento estratégico. 2015. 198 f. Tese (Doutorado) - Curso de Programa de Pós-graduação em Administração, Departamento de Ciências Administrativas, Universidade Federal do Rio Grande do Norte, Natal, 2015.

MIORANDO, Rogério Feroldi; RIBEIRO, José Luis Duarte. Uma análise qualitativa da governança de TI em um programa de pós-graduação. 2014. 12 f. Monografia (Especialização) - Curso de Programa de Pós-graduação em Engenharia de Produção e Transportes, Universidade Federal do Rio Grande do Sul, Porto Alegre, 2014.

NATAL. ACS/CAERN. (Org.). Missão e Visão. 2013. Disponível em: <http://caern.com.br/Conteudo. asp?TRAN=ITEM\&TARG=122\&ACT;=\&PAGE=0\&PARM;=\&LBL=A+Caern>. Acesso em: 24 jul. 2017.

O ESCÂNDALO da Enron: saiba o que está acontecendo. O Estadão. São Paulo, p. 1-1. 07 fev. 2002. Disponível em: <http://economia.estadao.com.br/noticias/geral,o-escandalo-da-enron-saiba-o-queesta-acontecendo,20020207p24521 >. Acesso em: 06 jul. 2017.

OLIVEIRA, Luiz Carlos de. Governança de TI: Proposta de um modelo para os Tribunais de Contas Estaduais. 2009. 131 f. Dissertação (Mestrado) - Curso de Ciências da Computação, Centro de Informática, Ufpe, Recife, 2009.

PAULO FREIRE (Rio Grande do Norte). Acs (Org.). Caern está entre as 250 melhores empresas do país. 2014. Disponível em: <http://www.caern.com.br/Conteudo. asp?TRAN=ITEM\&TARG=40465\&ACT;=\&PAGE;=\&PARM;=\&LBL=MATERIA>. Acesso em: 24 jul. 2017.

RODRIGUES, Alexandra Silva. Governança de TI: alinhamento que agrega valor ao negócio. Disponível em: <http://www.seer.ufrgs.br/ProdutoProducao/article/download/34567/28684>. Acesso em: 20 ago. 2017. 


\section{ISSN - 2447-178X}

ROTTA, C. HILLBRECHT, R. O. BALBINOTTO NETO, G. A Governança Corporativa no mundo. In: Encontro da Associação Nacional de Programas de Pós-Graduação em Administração, 2005, Brasília. Anais... Brasília: ANPAD, 2005

SILVEIRA, Alexandre Di Miceli da. Governança corporativa, desempenho e valor da empresa no Brasil. 2002. Dissertação (Mestrado em Administração) - Faculdade de Economia, Administração e Contabilidade, Universidade de São Paulo, São Paulo, 2002.Disponível em: <http://www.teses.usp.br/teses/disponiveis/12/12139/tde-04122002-102056/>. Acesso em: 2013-08-08.

WEILL, P.; Ross, J. W. IT governance - How top performers manage IT decision rights for superior results. Harvard Business School Press. 2004. Tradução de Roger Maioli dos Santos. São Paulo. M. Books do Brasil, 2006. 